\title{
Research Article \\ Effect of the Key Mixture Parameters on Shrinkage of Reactive Powder Concrete
}

\author{
Shamsad Ahmad, ${ }^{1}$ Ahmed Zubair, ${ }^{1}$ and Mohammed Maslehuddin ${ }^{2}$ \\ ${ }^{1}$ Civil and Environmental Engineering Department, King Fahd University of Petroleum and Minerals, \\ Dhahran 31261, Saudi Arabia \\ ${ }^{2}$ Research Institute, King Fahd University of Petroleum and Minerals, Dhahran 31261, Saudi Arabia \\ Correspondence should be addressed to Shamsad Ahmad; shamsad@kfupm.edu.sa
}

Received 8 May 2014; Accepted 3 June 2014; Published 23 June 2014

Academic Editor: F. Pacheco-Torgal

Copyright (C) 2014 Shamsad Ahmad et al. This is an open access article distributed under the Creative Commons Attribution License, which permits unrestricted use, distribution, and reproduction in any medium, provided the original work is properly cited.

Reactive powder concrete (RPC) mixtures are reported to have excellent mechanical and durability characteristics. However, such concrete mixtures having high amount of cementitious materials may have high early shrinkage causing cracking of concrete. In the present work, an attempt has been made to study the simultaneous effects of three key mixture parameters on shrinkage of the RPC mixtures. Considering three different levels of the three key mixture factors, a total of 27 mixtures of RPC were prepared according to $3^{3}$ factorial experiment design. The specimens belonging to all 27 mixtures were monitored for shrinkage at different ages over a total period of 90 days. The test results were plotted to observe the variation of shrinkage with time and to see the effects of the key mixture factors. The experimental data pertaining to 90-day shrinkage were used to conduct analysis of variance to identify significance of each factor and to obtain an empirical equation correlating the shrinkage of RPC with the three key mixture factors. The rate of development of shrinkage at early ages was higher. The water to binder ratio was found to be the most prominent factor followed by cement content with the least effect of silica fume content.

\section{Introduction}

Reactive powder concrete (RPC), also known as ultrahigh performance concrete (UHPC), is produced by mixing water, Portland cement, silica fume, fine quartz sand, quartz powder, superplasticizer, and steel fibers. The microstructure of RPC is made highly dense as it is prepared with a very low water to binder ratio $(0.15$ to 0.20$)$, high cement content (800 to $1100 \mathrm{~kg} / \mathrm{m}^{3}$ ), high silica fume content (20 to $25 \%$ of the weight of cement), well-graded fine sand and quartz powder (without using coarse aggregate), and steel fibers (about $6 \%$ by volume of RPC) [1]. The dense microstructure and presence of steel fibers in RPC mixtures provide superior mechanical properties (high strength, ductility, and toughness) and durability characteristics compared to conventional high performance concretes $[2,3]$. However, due to use of high amounts of cement and silica fume at a very low water to binder ratio in preparing the RPC mixtures, the risk of high autogenous shrinkage at early ages cannot be ruled out.
In normal concrete, total shrinkage is taken as the sum of drying shrinkage (due to loss of moisture through evaporation) and autogenous shrinkage (due to consumption of water for continued hydration of cementitious materials after initial setting through a process termed as self-desiccation). The autogenous shrinkage in normal concrete is found to be very small particularly when the water to cement ratio is above 0.42 . However, due to low water to binder ratio and high silica fume content used for producing the RPC mixtures, high self-desiccation takes place causing autogenous shrinkage of high order of magnitude $[1,4]$. Self-desiccation of paste in concrete, which takes place due to continued hydration of cementitious materials at very low water to binder ratio and high silica fume content, results in decline in its autogenous relative humidity which leads to the autogenous shrinkage. Initially, the internal relative humidity is high but, with the progress of self-desiccation, the internal relative humidity decreases at faster rate causing autogenous shrinkage at high rate. Loukili et al. [1] have reported 1-day and 10-day 
autogenous shrinkage as $45 \%$ and $95 \%$ of the final autogenous shrinkage, respectively, for RPC with a water to binder ratio of 0.20 and silica fume content of $24 \%$ by the mass of cement. This indicates the fast occurrence of autogenous shrinkage to a level near to the ultimate value at an early stage; however, with passage of time, the rate of decrease in the internal relative humidity falls due to decrease in internal temperature and moisture, thereby decreasing the rate of selfdesiccation and therefore the rate of autogenous shrinkage leading towards steady-state condition $[1,4-6]$. Tazawa and Miyazawa [7] have reported that, at very low water to binder ratio (around 0.17 ), the autogenous shrinkage of concrete could be nearly the same as drying shrinkage.

The risk of autogenous shrinkage increases with decrease in the water to binder ratio and with increase or decrease of the amount of the mineral admixtures depending on their types and chemical and physical properties [4, 8-10]. Jiang et al. [8] have reported a sharp decrease in the autogenous relative humidity at lower water to binder ratio and increased amount of the mineral admixtures increasing the chances of more autogenous shrinkage. However, the lowering of water to binder ratio increased the autogenous shrinkage more than the increasing of the dosage of mineral admixtures. Unlike the autogenous shrinkage, the drying shrinkage in RPC decreases with decrease in the water to binder ratio $[10,11]$. For concrete with low water to binder ratio, both fly ash and slag decrease the drying shrinkage while silica fume increases the drying shrinkage depending on other factors such as curing time, measurement method, curing type, cement replacement ratios, and so forth. On the other hand, while the addition of fly ash reduces the autogenous shrinkage, the addition of slag or silica fume increases the autogenous shrinkage [10]. While the use of a high dosage of superplasticizer increases the drying shrinkage [11], the expansive and shrinkage reducing admixtures can decrease the shrinkage in RPC mixtures significantly $[12,13]$. The use of superabsorbent polymers has been reported to be effective in reducing the autogenous shrinkage [14]. The rice husk ash is also found to be useful in mitigating the autogenous shrinkage in the RPC mixtures [15]. The effect of the steel fibers in RPC mixtures is to reduce the shrinkage by restraining effect offered by the fibers $[1,16]$. Garas et al. [17] have reported a reduction in free shrinkage by about $50 \%$ and autogenous shrinkage by about $42 \%$ by adding $2 \%$ of steel fibers (by volume) to RPC mixture.

While the effect of the various parameters (water to binder ratio, mineral admixtures, superplasticizer, shrinkage reducing admixtures, steel fibers, etc.) on the shrinkage of RPC mixtures is reported individually in the literature, the simultaneous effects of the key mixture parameters such as water to binder ratio, cement content, and silica fume content on shrinkage are rarely addressed. If the shrinkage is quantitatively correlated to the key mixture parameters, the mixture proportions can be optimized to keep the shrinkage of RPC mixtures within the permissible limits. In the present work, an attempt has been made to study the simultaneous effects of three key mixture parameters (water to binder ratio, cement content, and silica fume content) on shrinkage of the RPC mixtures. Considering three different levels of
TABLE 1: Chemical composition of cement and silica fume.

\begin{tabular}{lcc}
\hline Constituent & Cement (\%) & Silica fume (\%) \\
\hline $\mathrm{CaO}$ & 64.35 & 0.41 \\
$\mathrm{SiO}_{2}$ & 22.0 & 86.75 \\
$\mathrm{Al}_{2} \mathrm{O}_{3}$ & 5.64 & 0.41 \\
$\mathrm{Fe}_{2} \mathrm{O}_{3}$ & 3.80 & 2.12 \\
$\mathrm{~K}_{2} \mathrm{O}$ & 0.36 & 0.67 \\
$\mathrm{MgO}$ & 2.11 & 0.18 \\
$\mathrm{Na}_{2} \mathrm{O}$ & 0.19 & 0.17 \\
$\mathrm{Equivalent}$ alkalis & 0.33 & 0.62 \\
$\left(\mathrm{Na}_{2} \mathrm{O}+0.658 \mathrm{~K}_{2} \mathrm{O}\right)$ & 2.10 & 0.73 \\
$\mathrm{SO}_{3}$ & 0.70 & 3.35 \\
Loss on ignition & & \\
\hline
\end{tabular}

TABLE 2: Dune sand grading.

\begin{tabular}{lc}
\hline Sieve opening, $\mathrm{mm}$ & \% passing \\
\hline 4.75 & 100 \\
2.4 & 100 \\
1.2 & 100 \\
0.6 & 96.2 \\
0.3 & 61.4 \\
0.15 & 21.9 \\
0.075 & 1.0 \\
\hline
\end{tabular}

the three key mixture factors, a total of 27 mixtures of RPC were prepared according to $3^{3}$ factorial experiment design. The specimens belonging to all 27 mixtures were monitored for shrinkage at different ages over a total period of 90 days. The test results were plotted to observe the variation of shrinkage with time and to see the effects of the key mixture factors. The experimental data pertaining to 90-day shrinkage (ultimate shrinkage) were used to conduct analysis of variance (ANOVA) to identify significance of each factor and to obtain an empirical equation correlating the shrinkage of RPC with the three key mixture factors.

\section{Experimental Program}

\subsection{Materials}

2.1.1. Cement and Silica Fume. Type I cement (ordinary Portland cement) conforming to ASTM C 150 [18] with a specific gravity of 3.15 and chemical composition, as shown in Table 1, was used in all the mixtures of RPC. The chemical composition of the silica fume used is also shown in Table 1.

2.1.2. Fine Dune Sand. Fine dune sand obtained from the deserts of Saudi Arabia, with water absorption of $0.5 \%$ and specific gravity of 2.53 , was used as aggregate. The natural grading of sand used in all the mixtures is shown in Table 2.

2.1.3. Superplasticizer and Steel Fibers. A liquid superplasticizer (commercial name: Glenium 51) was used to obtain 
TABLE 3: Weights of the constituents of 27 RPC mixtures (for $1 \mathrm{~m}^{3}$ ).

\begin{tabular}{|c|c|c|c|c|c|c|c|c|c|c|}
\hline Mix ID & $\mathrm{w} / \mathrm{b}$ ratio & $\begin{array}{l}\text { Cement } \\
(\mathrm{kg})\end{array}$ & $\begin{array}{c}\text { Silica fume } \\
(\%)\end{array}$ & $\begin{array}{c}\text { Silica fume } \\
(\mathrm{kg})\end{array}$ & $\begin{array}{l}\text { Water } \\
(\mathrm{kg})\end{array}$ & $\begin{array}{c}\text { Fiber } \\
(\mathrm{kg})\end{array}$ & SP (\%) & SP (kg) & $\begin{array}{l}\text { Sand } \\
(\mathrm{kg})\end{array}$ & $\begin{array}{c}\text { Effective w/b ratio } \\
\text { considering water in SP }\end{array}$ \\
\hline M1 & 0.15 & 1000 & 15 & 150 & 173 & 157 & 3.55 & 41 & 977 & 0.183 \\
\hline M2 & 0.15 & 1000 & 20 & 200 & 180 & 157 & 3.55 & 43 & 898 & 0.182 \\
\hline M3 & 0.15 & 1000 & 25 & 250 & 188 & 157 & 3.55 & 44 & 818 & 0.182 \\
\hline M4 & 0.15 & 1100 & 15 & 165 & 190 & 157 & 3.55 & 45 & 827 & 0.182 \\
\hline M5 & 0.15 & 1100 & 20 & 220 & 198 & 157 & 3.55 & 47 & 739 & 0.182 \\
\hline M6 & 0.15 & 1100 & 25 & 275 & 206 & 157 & 3.55 & 49 & 652 & 0.182 \\
\hline M7 & 0.15 & 1200 & 15 & 180 & 207 & 157 & 3.55 & 49 & 676 & 0.182 \\
\hline M8 & 0.15 & 1200 & 20 & 240 & 216 & 157 & 3.55 & 51 & 581 & 0.182 \\
\hline M9 & 0.15 & 1200 & 25 & 300 & 225 & 157 & 3.55 & 53 & 486 & 0.182 \\
\hline M10 & 0.175 & 1000 & 15 & 150 & 201 & 157 & 2 & 23 & 945 & 0.193 \\
\hline M11 & 0.175 & 1000 & 20 & 200 & 210 & 157 & 2 & 24 & 865 & 0.193 \\
\hline M12 & 0.175 & 1000 & 25 & 250 & 219 & 157 & 2 & 25 & 784 & 0.193 \\
\hline M13 & 0.175 & 1100 & 15 & 165 & 221 & 157 & 1.5 & 19 & 806 & 0.188 \\
\hline M14 & 0.175 & 1100 & 20 & 220 & 231 & 157 & 1.5 & 20 & 718 & 0.189 \\
\hline M15 & 0.175 & 1100 & 25 & 275 & 241 & 157 & 1.5 & 21 & 630 & 0.189 \\
\hline M16 & 0.175 & 1200 & 15 & 180 & 242 & 157 & 1.5 & 21 & 654 & 0.189 \\
\hline M17 & 0.175 & 1200 & 20 & 240 & 252 & 157 & 1.5 & 22 & 558 & 0.189 \\
\hline M18 & 0.175 & 1200 & 25 & 300 & 263 & 157 & 1.5 & 23 & 462 & 0.189 \\
\hline M19 & 0.20 & 1000 & 15 & 150 & 230 & 157 & 1.5 & 17 & 886 & 0.213 \\
\hline M20 & 0.20 & 1000 & 20 & 200 & 240 & 157 & 1.5 & 18 & 803 & 0.214 \\
\hline M21 & 0.20 & 1000 & 25 & 250 & 250 & 157 & 1.5 & 19 & 719 & 0.214 \\
\hline M22 & 0.20 & 1100 & 15 & 165 & 253 & 157 & 1 & 13 & 741 & 0.209 \\
\hline M23 & 0.20 & 1100 & 20 & 220 & 264 & 157 & 1 & 13 & 650 & 0.209 \\
\hline M24 & 0.20 & 1100 & 25 & 275 & 275 & 157 & 1 & 14 & 559 & 0.209 \\
\hline M25 & 0.20 & 1200 & 15 & 180 & 276 & 157 & 1 & 14 & 583 & 0.209 \\
\hline M26 & 0.20 & 1200 & 20 & 240 & 288 & 157 & 1 & 14 & 484 & 0.209 \\
\hline M27 & 0.20 & 1200 & 25 & 300 & 300 & 157 & 1 & 15 & 385 & 0.209 \\
\hline
\end{tabular}

the desired flow. Glenium 51 is a polycarboxylic ether (PCE) based superplasticizer which does not contain chlorides and complies with ASTM C494 [19] Types A and F. The specific gravity of Glenium 51 was 1.095 with $65 \%$ water content by weight. Varying dosage of this superplasticizer was used to obtain a flow of $200 \pm 20 \mathrm{~mm}$ for all the mixtures using ASTM C1437 (standard test method for measuring flow of hydraulic cement mortar) [20]. Steel fibres of $0.22 \mathrm{~mm}$ diameter and $13 \mathrm{~mm}$ length with tensile strength greater than $2850 \mathrm{MPa}$ were used in all the mixtures.

2.2. RPC Mixtures. Three key mixture parameters, namely, water/binder ratio, cement content, and silica fume content, were considered with their three levels of variation for studying the effect of these mixture parameters on the shrinkage of a total of 27 RPC mixtures as per $3^{3}$ factorial experiment design. The three levels of each parameter, selected within their practical ranges for producing RPC, are given below:

$$
\begin{aligned}
& \text { water/binder }(\mathrm{w} / \mathrm{b}) \text { ratio: } 0.15,0.175 \text {, and } 0.20 \text {; } \\
& \text { cement content }\left(\mathrm{kg} / \mathrm{m}^{3}\right): 1000,1100 \text {, and } 1200 \text {; } \\
& \text { silica fume content }(\% \text { of cement): } 15,20 \text {, and } 25 \text {. }
\end{aligned}
$$

Steel fiber content of $157 \mathrm{~kg} / \mathrm{m}^{3}$ was used in all the mixtures. Absolute volume method was used to design the mixtures. The weights of constituents determined for producing one cubic meter of each of the RPC mixtures are presented in Table 3.

2.3. Preparation of Test Specimens. Since RPC is composed of very fine materials; special attention was needed for mixing. The procedure recommended in the literature [2123] for mixing of RPC was followed. After mixing, the RPC was poured into the molds and consolidated using a 


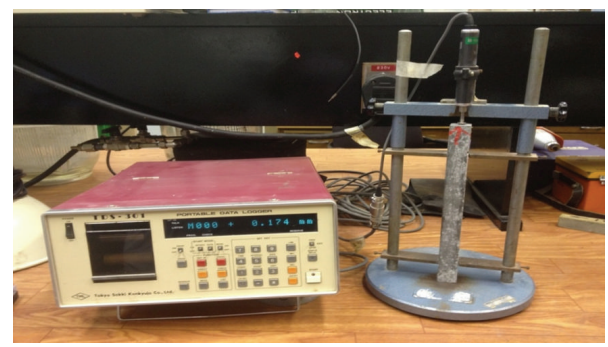

FIGURE 1: Setup for measuring total shrinkage.

vibrating table. A total of 81prisms of size $25 \times 25 \times 275 \mathrm{~mm}$ (27 mixtures $\times 3$ replicates) were cast for monitoring the drying shrinkage. The specimens were first cured in a water tank for 3 days after casting. After 3 days of water-curing, specimens were taken out of the tank and the surfaces were allowed to dry before starting the shrinkage monitoring in the laboratory conditions $\left(50 \%\right.$ relative humidity and $25^{\circ} \mathrm{C}$ temperature).

2.4. Monitoring Total Shrinkage of the Specimens. Total shrinkage of the specimens belonging to all 27 mixtures of RPC was measured at 3, 7, 14, 21, 28, 42, 56, and 90 days after casting according to ASTM C157 [24]. For each mixture, total shrinkage was measured at a time on a set of three similar specimens and average of three measured values of total shrinkage was reported. A setup consisting of a stand fitted with a LVDT connected to a data logger was used, as shown in Figure 1.

\section{Results and Discussion}

3.1. Effect of Age on Shrinkage. The plots showing the variation of the total shrinkage of the mixtures of RPC with age are shown in Figures 2, 3, and 4. It can be seen from Figures 2 through 4 that the rate of development of shrinkage is higher at the early stages and almost a steady-state condition is observed in case of all the mixtures at the age of 90 days. The shrinkage at $3,7,14,21,28,42$, and 56 days were found in the ranges of 33 to 54,48 to 65,58 to 77,67 to 85,78 to 91,89 to 96 , and 95 to $99 \%$ of the 90 -day shrinkage (i.e., typically ultimate shrinkage), respectively. It can be noted that more than one-third, one-half, and two-thirds of ultimate shrinkage occurred at the early ages of 3, 7, and 14 days.

3.2. Effects of Mixture Parameters on Shrinkage. From the observation of Figures 2 through 4 , it can be seen that with increase in the $\mathrm{w} / \mathrm{b}$ ratio the total shrinkage increases. However, the increase in the total shrinkage with increase of $\mathrm{w} / \mathrm{b}$ ratio from 0.15 to 0.175 is almost negligible particularly at cement content above $1000 \mathrm{~kg} / \mathrm{m}^{3}$. This is because of the fact that, at an intended w/b ratio of 0.15 , the required amount of superplasticizer is very high resulting in an effective $w / b$ ratio almost similar to that for the intended w/b ratio of 0.175 , as evident from the values of effective $\mathrm{w} / \mathrm{b}$ ratios presented in the last column of Table 3. There is significant increase in the shrinkage when $\mathrm{w} / \mathrm{b}$ ratio was increased from 0.175 to 0.20 because there is significant difference between the corresponding effective $\mathrm{w} / \mathrm{b}$ ratios also due to relatively lower amount of superplasticizer required at the intended $\mathrm{w} / \mathrm{b}$ ratios of 0.175 and 0.2 , particularly for the cement content of more than $1000 \mathrm{~kg} / \mathrm{m}^{3}$.

A significant increase in the shrinkage with increase in cement content can be observed from Figures 2 through 4 . It can be further noted that the increase in the shrinkage is more significant when cement content was increased from 1000 to $1100 \mathrm{~kg} / \mathrm{m}^{3}$ as compared to increase in shrinkage due to increase in cement content from 1100 to $1200 \mathrm{~kg} / \mathrm{m}^{3}$. The reason behind insignificant increase in the shrinkage when cement content in the present study was increased from 1100 to $1200 \mathrm{~kg} / \mathrm{m}^{3}$ may be attributed to the following fact. Although, with increase in the cement content, selfdesiccation increases causing more shrinkage, beyond certain point, the self-desiccation helps in hydrating the cement partially and the additional cement mostly remains unhydrated limiting the effect of increase in the cement content on the shrinkage. Further, it may be noted that the effect of cement content on shrinkage is higher at lower w/b ratio and lower silica fume content.

The effect of increase in the silica fume content in the range of 15 to $25 \%$ was found to be marginal at cement content of $1000 \mathrm{~kg} / \mathrm{m}^{3}$. However, the effect of increase in the silica fume content was insignificant at cement content above $1000 \mathrm{~kg} / \mathrm{m}^{3}$.

3.3. Statistical Analysis of the 90-Day Shrinkage Test Results. In order to compare the significance of each of the three key mixture factors on shrinkage, the analysis of variance (ANOVA) was conducted using 90-day shrinkage (ultimate shrinkage) data. The ANOVA results ( $F$-ratios), as summarized in Table 4, indicate that the $\mathrm{w} / \mathrm{b}$ ratio has most significant effect followed by cement content with the least effect of silica fume content. The variation of the shrinkage with the selected key mixture parameters indicates the possibility of optimizing the mixtures of RPC if a regression equation correlating shrinkage with the mixture parameters is obtained utilizing the experimental data generated through the present work.

The regression equation relating the 90-day shrinkage to the $\mathrm{w} / \mathrm{b}$ ratio, cement content, and silica fume content is given as follows:

$$
\begin{array}{r}
S_{h}=2401 W+0.529 C+0.247 S-445 \\
{\left[R^{2}=0.99\right],}
\end{array}
$$

where $S_{h}$ is 90 -day shrinkage (microstrain), $W$ is w/b ratio (by mass), $C$ is cement content $\left(\mathrm{kg} / \mathrm{m}^{3}\right), S$ is silica fume content $\mathrm{Kg} / \mathrm{m}^{3}$.

The above regression equation indicates that an increase in the paste volume due to higher cement and mineral additive content is one of the main reasons of higher ultimate shrinkage for RPC. This is in agreement with the fact that more paste (i.e., less aggregate) in concrete increases the shrinkage [25]. The equation obtained for the ultimate shrinkage can be used to optimize the levels of $w / b$ ratio, 


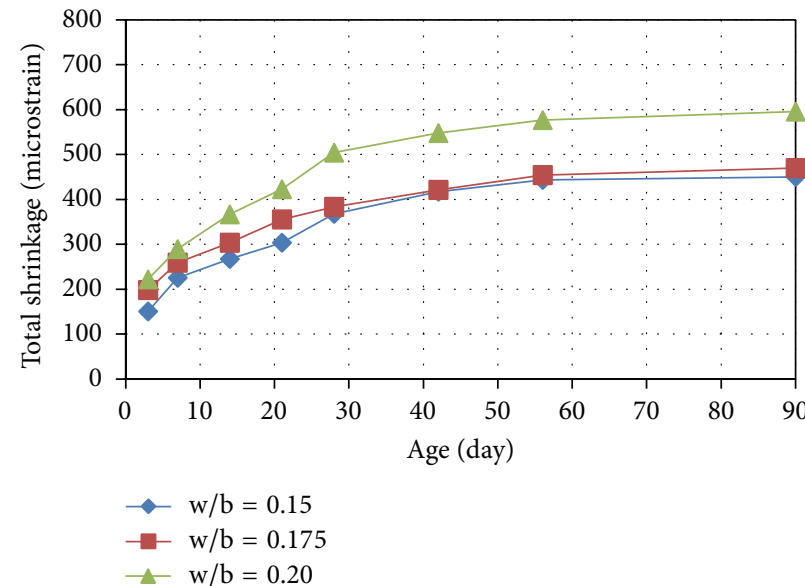

(a) $\mathrm{SF}=15 \%$

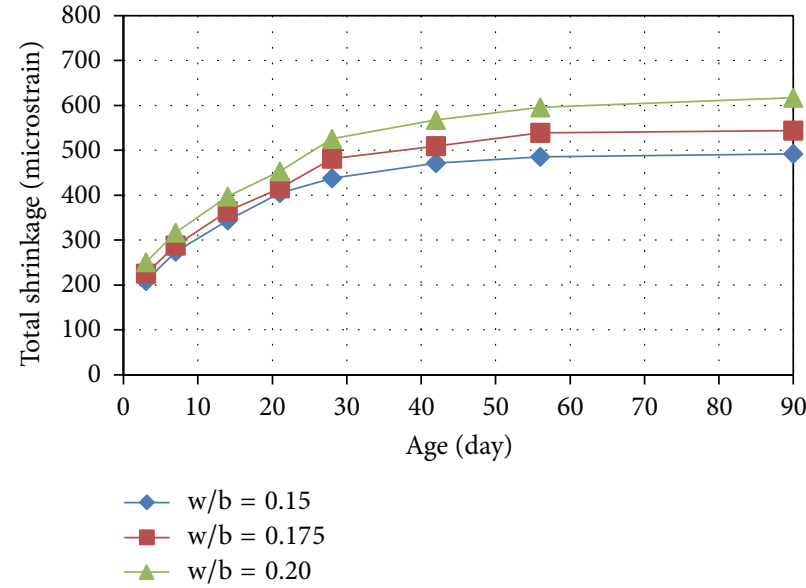

(b) $\mathrm{SF}=20 \%$

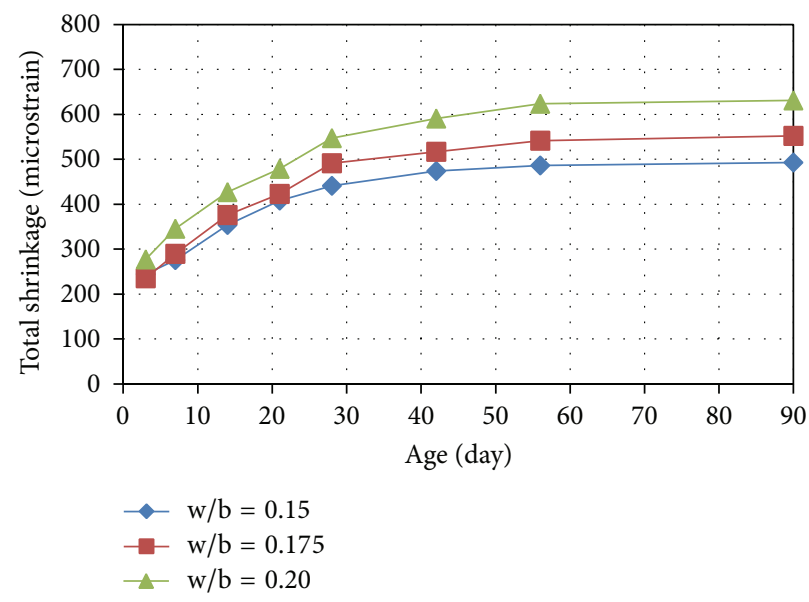

(c) $\mathrm{SF}=25 \%$

FIGURE 2: Variation of total shrinkage of RPC mixtures (having cement content of $1000 \mathrm{~kg} / \mathrm{m}^{3}$ ) with age.

TABLE 4: Results of the ANOVA of the ultimate shrinkage (90-day) data.

\begin{tabular}{|c|c|c|c|c|c|c|}
\hline Factor & Type & Levels & \multicolumn{4}{|c|}{ Values } \\
\hline$W(\mathrm{w} / \mathrm{b}$ ratio $)$ & Fixed & 3 & \multicolumn{4}{|c|}{$0.150,0.175$, and 0.200} \\
\hline$C$ (cement content) & Fixed & 3 & \multicolumn{4}{|c|}{1000,1100 , and $1200 \mathrm{Kg} / \mathrm{m}^{3}$} \\
\hline$S$ (SF content) & Fixed & 3 & \multicolumn{4}{|c|}{15,20 , and $25 \%$ of cement content } \\
\hline \multicolumn{7}{|c|}{ Analysis of variance (ANOVA), using adjusted SS for tests } \\
\hline Source & $\begin{array}{c}\text { Degree of } \\
\text { freedom (DF) }\end{array}$ & $\begin{array}{c}\text { Sum squares } \\
\text { (SS) }\end{array}$ & $\begin{array}{l}\text { Adjusted } \\
\text { SS }\end{array}$ & $\begin{array}{l}\text { Adjusted mean sum } \\
\text { squares (MS) }\end{array}$ & $F$-ratio & $\begin{array}{c}\text { Probability of no } \\
\text { significance }(P) \\
\end{array}$ \\
\hline$W$ & 2 & 67027.4 & 67027.4 & 33513.7 & 358.68 & 0.000 \\
\hline$C$ & 2 & 62146.7 & 62146.7 & 31073.4 & 332.56 & 0.000 \\
\hline$S$ & 2 & 3029.3 & 3029.3 & 1514.6 & 16.21 & 0.002 \\
\hline$W * C$ & 4 & 2353.7 & 2353.7 & 588.4 & 6.30 & 0.014 \\
\hline$C * S$ & 4 & 2332.9 & 2332.9 & 583.2 & 6.24 & 0.014 \\
\hline$W * S$ & 4 & 313.6 & 313.6 & 78.4 & 0.84 & 0.537 \\
\hline Error & 8 & 747.5 & 747.5 & 93.4 & - & - \\
\hline \multirow[t]{2}{*}{ Total } & 26 & 137951.0 & - & - & - & - \\
\hline & & $S=9.66623$ & $-S q=99.46 \%$ & $R-S q(\operatorname{adj})=98.24 \%$ & & \\
\hline
\end{tabular}




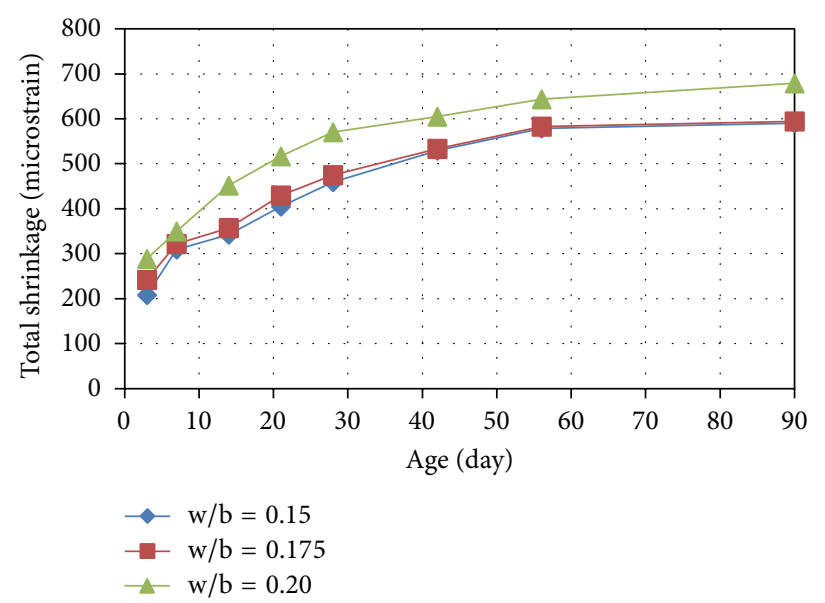

(a) $\mathrm{SF}=15 \%$

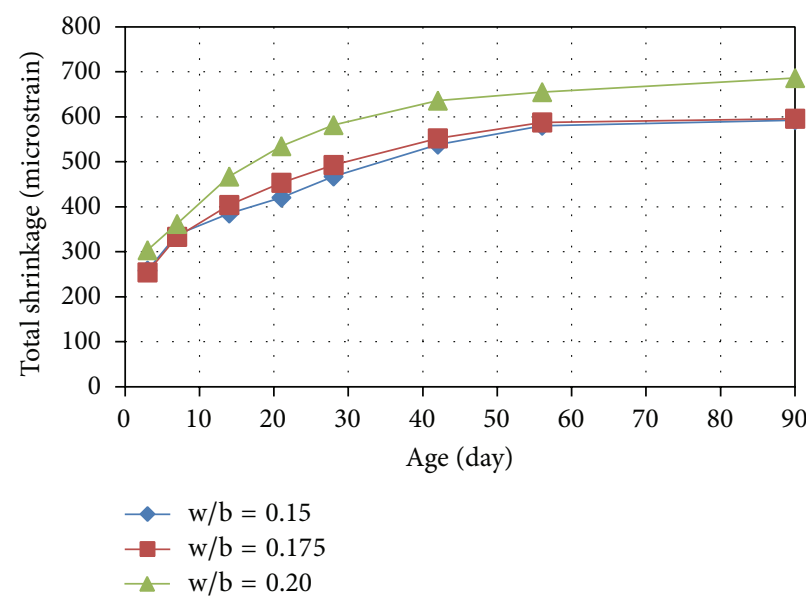

(b) $\mathrm{SF}=20 \%$

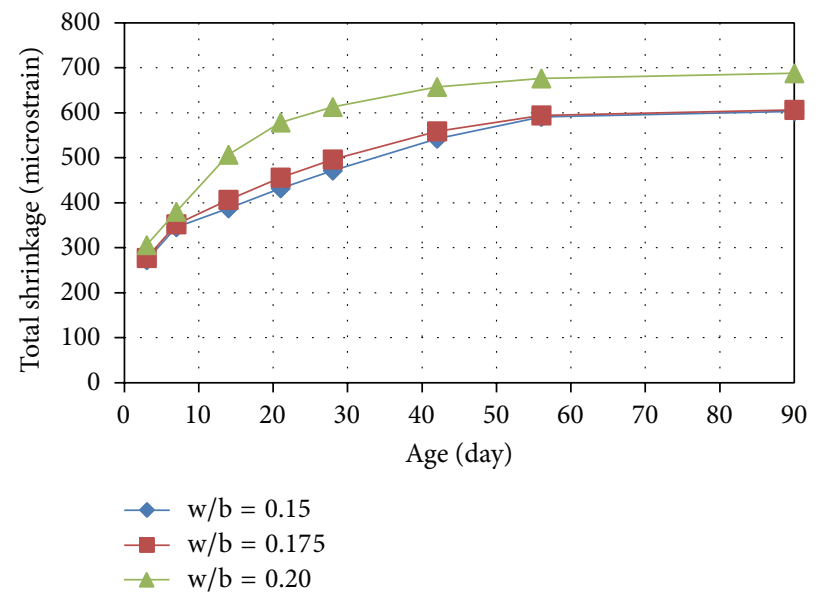

(c) $\mathrm{SF}=25 \%$

FIGURE 3: Variation of total shrinkage of RPC mixtures (having cement content of $1100 \mathrm{~kg} / \mathrm{m}^{3}$ ) with age.

cement content, and silica fume content (within their ranges of variations considered in this study) for keeping the ultimate shrinkage at a required maximum permissible limit.

\section{Conclusions}

Based on the findings of the present study, the following conclusions can be made.

(i) The shrinkage in all the RPC mixtures occurred at high rates at early stages and almost reached the steady-state condition after an exposure period of 90 days. More than one-third, one-half, and two-thirds of the ultimate shrinkage occurred at the early ages of 3,7 , and 14 days.

(ii) The increase in the total shrinkage with increase of $\mathrm{w} / \mathrm{b}$ ratio from 0.15 to 0.175 is almost negligible particularly at cement content above $1000 \mathrm{~kg} / \mathrm{m}^{3}$ because the effective $\mathrm{w} / \mathrm{b}$ ratios corresponding to the intended $\mathrm{w} / \mathrm{b}$ ratios of 0.15 and 0.175 were almost similar due to high requirement of superplasticizer at a w/b ratio of 0.15 . (iii) Increase in the shrinkage was more significant when cement content was increased from 1000 to $1100 \mathrm{~kg} / \mathrm{m}^{3}$ as compared to increase in shrinkage due to increase in cement content from 1100 to $1200 \mathrm{~kg} / \mathrm{m}^{3}$ due to the fact that the self-desiccation is not proportional to the cement content beyond a certain limit.

(iv) All the three key mixture parameters were found to increase the shrinkage with increase in their levels because of the increase in the paste content. The statistical analysis of the experimental data using ANOVA indicated that the w/b ratio affected shrinkage most significantly followed by the cement content with the least effect of the silica fume content.

(v) The regression equation obtained for the ultimate shrinkage of the RPC mixtures can be utilized to optimize the levels of $\mathrm{w} / \mathrm{b}$ ratio, cement content, and silica fume content (within their ranges of variations considered in this study) for keeping the ultimate shrinkage at a required maximum permissible limit. 


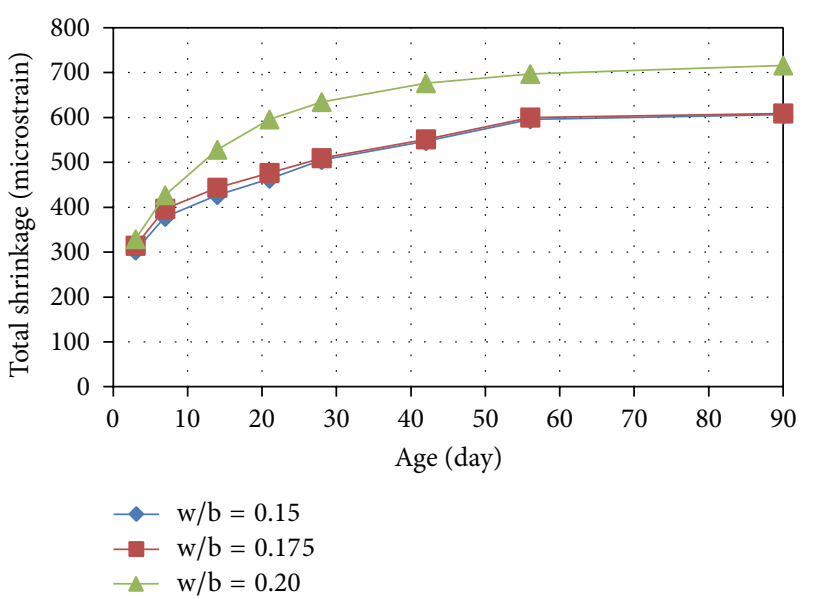

(a) $\mathrm{SF}=15 \%$

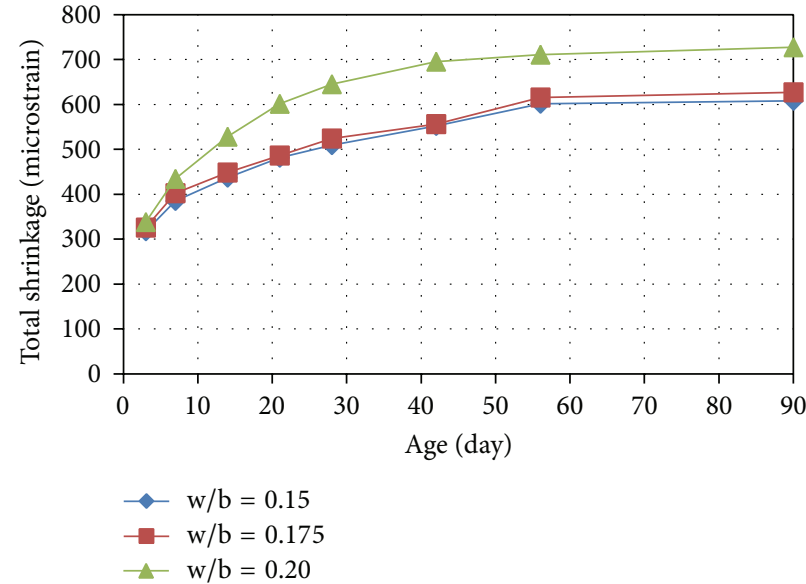

(b) $\mathrm{SF}=20 \%$

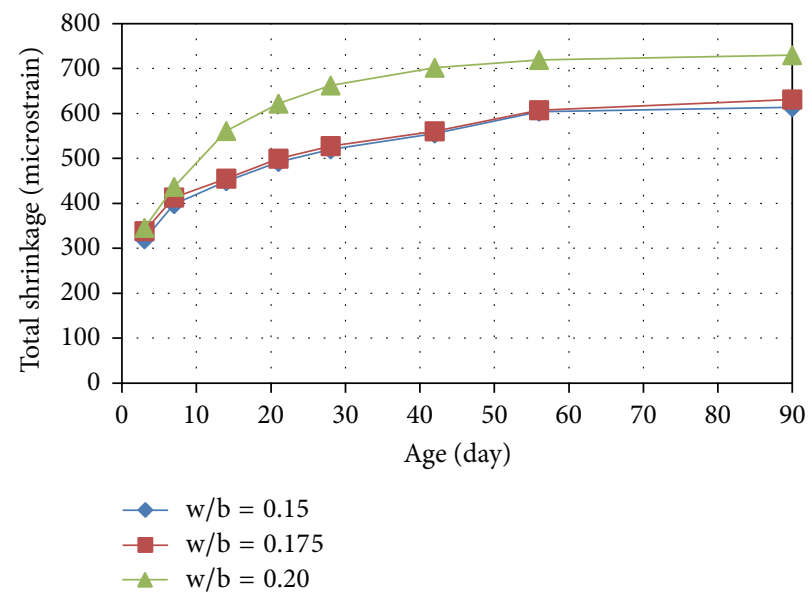

(c) $\mathrm{SF}=25 \%$

FIGURE 4: Variation of total shrinkage of RPC mixtures (having cement content of $1200 \mathrm{~kg} / \mathrm{m}^{3}$ ) with age.

\section{Conflict of Interests}

The authors declare that there is no conflict of interests regarding the publication of this paper.

\section{Acknowledgments}

The authors gratefully acknowledge the financial support provided by King Fahd University of Petroleum \& Minerals, Dhahran, Saudi Arabia, under research grant (Projects nos. RG1005-1 and RG1005-2). The logistical support of the Department of Civil \& Environmental Engineering and the Research Institute, King Fahd University of Petroleum \& Minerals, Dhahran, Saudi Arabia, is also acknowledged with appreciation.

\section{References}

[1] A. Loukili, A. Khelidj, and P. Richard, "Hydration kinetics, change of relative humidity, and autogenous shrinkage of ultrahigh-strength concrete," Cement and Concrete Research, vol. 29, no. 4, pp. 577-584, 1999.
[2] M. C. Andrade, M. Frias, and B. Aarup, "Durability of ultra high strength concrete: compact reinforced composite," in Proceedings of the 4th International Symposium on Utilization of High-Strength/High-Performance Concrete, pp. 529-534, ENPC Press, Paris, France, 1996.

[3] V. Y. G. Yanni, Multi-scale investigation of tensile creep of ultra high performance concrete for bridge applications [Ph.D. thesis], Georgia Institute of Technology, 2009.

[4] M. H. Zhang, C. T. Tam, and M. P. Leow, "Effect of water-tocementitious materials ratio and silica fume on the autogenous shrinkage of concrete," Cement and Concrete Research, vol. 33, no. 10, pp. 1687-1694, 2003.

[5] P. Lura, O. M. Jensen, and K. V. Breugel, "Autogenous shrinkage in high-performance cement paste: an evaluation of basic mechanisms," Cement and Concrete Research, vol. 33, no. 2, pp. 223-232, 2003.

[6] A. C. L. Wong, P. A. Childs, R. Berndt, T. Macken, G. Peng, and N. Gowripalan, "Simultaneous measurement of shrinkage and temperature of reactive powder concrete at early-age using fibre Bragg grating sensors," Cement and Concrete Composites, vol. 29, no. 6, pp. 490-497, 2007. 
[7] E. Tazawa and S. Miyazawa, "Experimental study on mechanism of autogenous shrinkage of concrete," Cement and Concrete Research, vol. 25, no. 8, pp. 1633-1638, 1995.

[8] Z. Jiang, Z. Sun, and P. Wang, "Autogenous relative humidity change and autogenous shrinkage of high-performance cement pastes," Cement and Concrete Research, vol. 35, no. 8, pp. 15391545, 2005.

[9] F. Ghassemzadeh, M. Shekarchi, S. Sajedi, M. Khanzadeh, and S. Sadati, "Effect of silica fume and GGBS on shrinkage in the high performance concrete," in Proceedings of the 6th International Conference on Concrete under Severe Conditions-Environment and Loading (CONSEC '10), pp. 1007-1012, June 2010.

[10] J. Liu, W. Sun, and C. Miao, "Effect of mineral admixtures on drying and autogenous shrinkage of concrete with low waterto-binder ratio," Journal of Southeast University, vol. 39, no. 3, pp. 580-585, 2009.

[11] C. M. Tam, V. W. Y. Tam, and K. M. Ng, "Assessing drying shrinkage and water permeability of reactive powder concrete produced in Hong Kong," Construction and Building Materials, vol. 26, no. 1, pp. 79-89, 2012.

[12] J. Park, S. Kim, G. Ryu, and K. Lee, "The influence of chemical admixtures on the autogenous shrinkage ultra-high performance concrete," Key Engineering Materials, vol. 452-453, pp. 725-728, 2011.

[13] J. Park, D. Yoo, S. Kim, and Y. Yoon, "Combined influence of expansive and shrinkage reducing admixtures on the shrinkage behavior of ultra-high performance concrete," Key Engineering Materials, vol. 488-489, pp. 242-245, 2012.

[14] L. Dudziak and V. Mechtcherine, "Reducing the cracking potential of ultra-high performance concrete by using Super Absorbent Polymers (SAP)," in Proceedings of the International Conference on Advanced Concrete Materials (ACM '09), pp. 1119, November 2009.

[15] G. Ye and V. T. Nguyen, "Mitigation of autogenous shrinkage of ultra-high performance concrete by rice husk ash," Journal of the Chinese Ceramic Society, vol. 40, no. 2, pp. 212-216, 2012.

[16] S. Allena and C. M. Newtson, "Shrinkage of ultra-high strength concrete," Indian Concrete Journal, vol. 87, no. 12, pp. 53-62, 2013.

[17] V. Y. Garas, L. F. Kahn, and K. E. Kurtis, "Preliminary investigation of the effect of steel fibers on the tensile creep and shrinkage of ultra-high performance concrete," in Proceedings of the 8th International Conference on Creep, Shrinkage and Durability Mechanics of Concrete and Concrete Structures, vol. 1, pp. 741744, October 2008.

[18] ASTM C150, Standard Specification for Portland Cement, ASTM International, West Conshohocken, Pa, USA, 2012.

[19] ASTM C494, Standard Specification for Chemical Admixtures for Concrete, ASTM International, West Conshohocken, Pa, USA, 2013.

[20] ASTM C1437, Standard Test Method for Flow of Hydraulic Cement Mortar, ASTM International, West Conshohocken, Pa, USA, 2013.

[21] O. Mazanec, D. Lowke, and P. Schiel, "Mixing of high performance concrete: effect of concrete composition and mixing intensity on mixing time," Materials and Structures, vol. 43, no. 3, pp. 357-365, 2010.

[22] K. M. Ng, C. M. Tam, and V. W. Y. Tam, "Studying the production process and mechanical properties of reactive powder concrete: a Hong Kong study," Magazine of Concrete Research, vol. 62, no. 9, pp. 647-654, 2010.
[23] C. M. Tam, V. W. Y. Tam, and K. M. Ng, "Optimal conditions for producing reactive powder concrete," Magazine of Concrete Research, vol. 62, no. 10, pp. 701-716, 2010.

[24] ASTM C157, Standard Test Method for Length Change of Hardened Hydraulic-Cement Mortar and Concrete, ASTM International, West Conshohocken, Pa, USA, 2008.

[25] G. Pickett, "Effect of aggregate on shrinkasge of concrete and hypothesis concerning shrinkage," Journal of American Concrete Institute, vol. 52, pp. 581-590, 1956. 

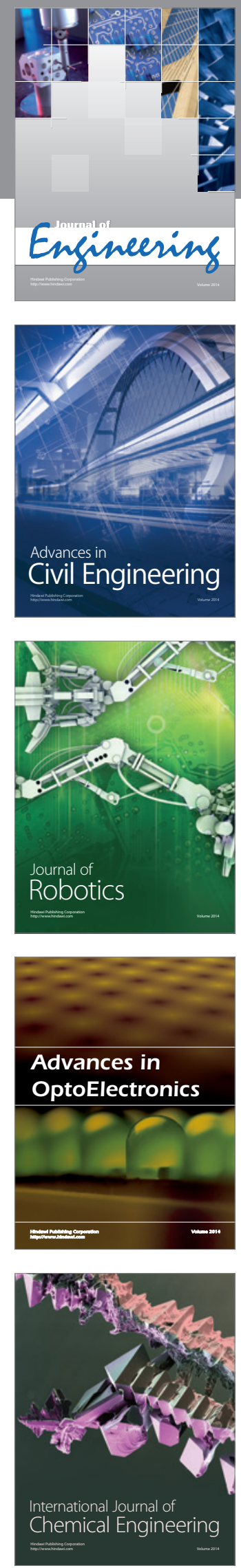

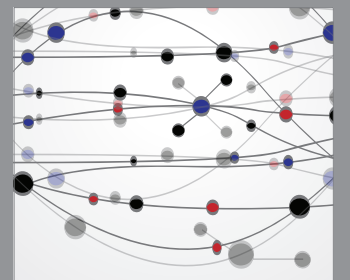

The Scientific World Journal
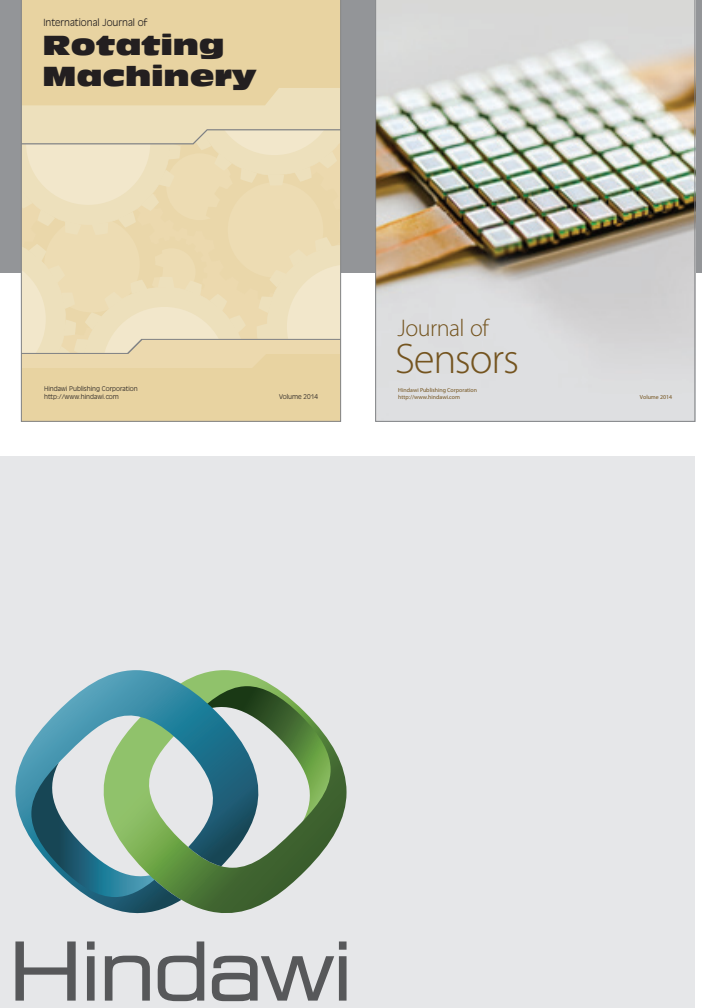

Submit your manuscripts at http://www.hindawi.com
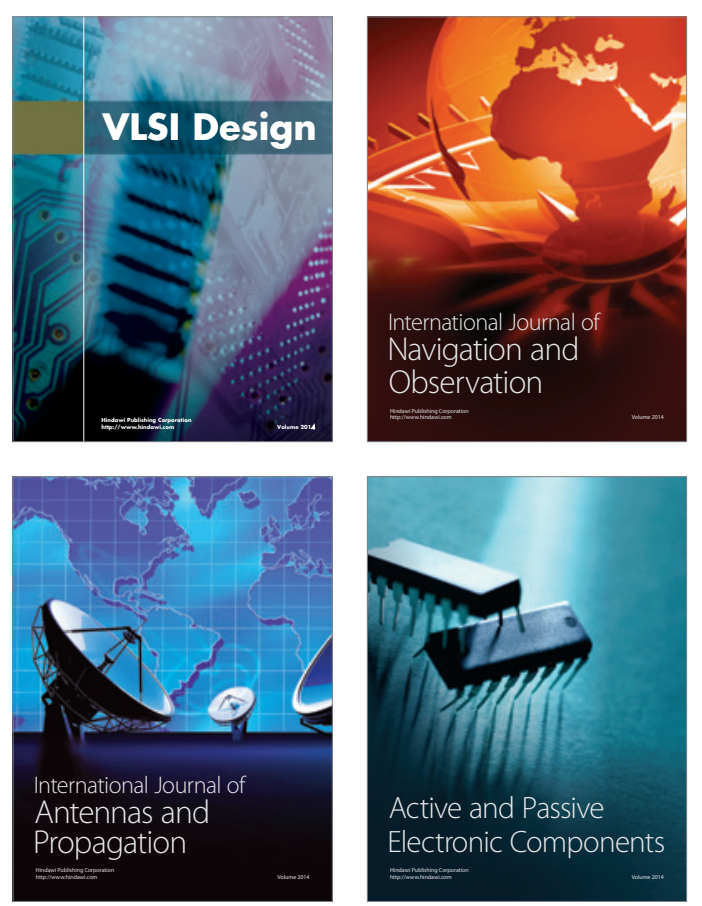
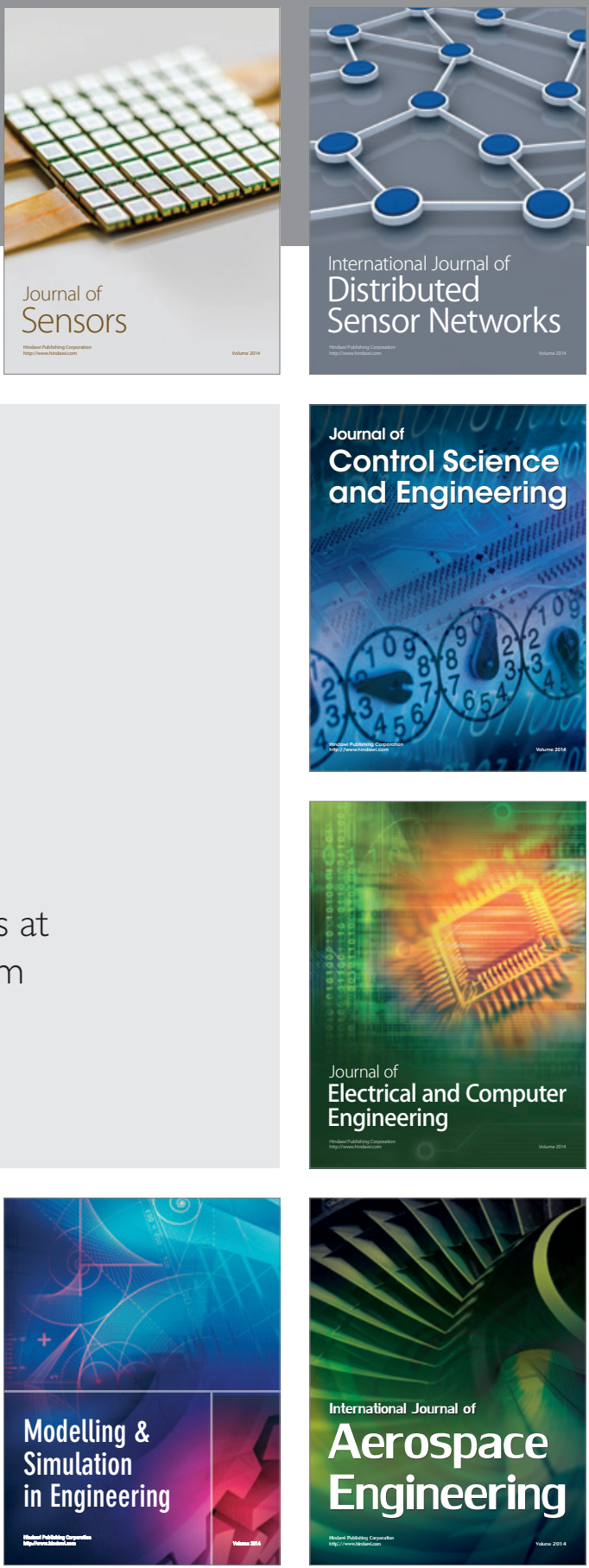

Journal of

Control Science

and Engineering
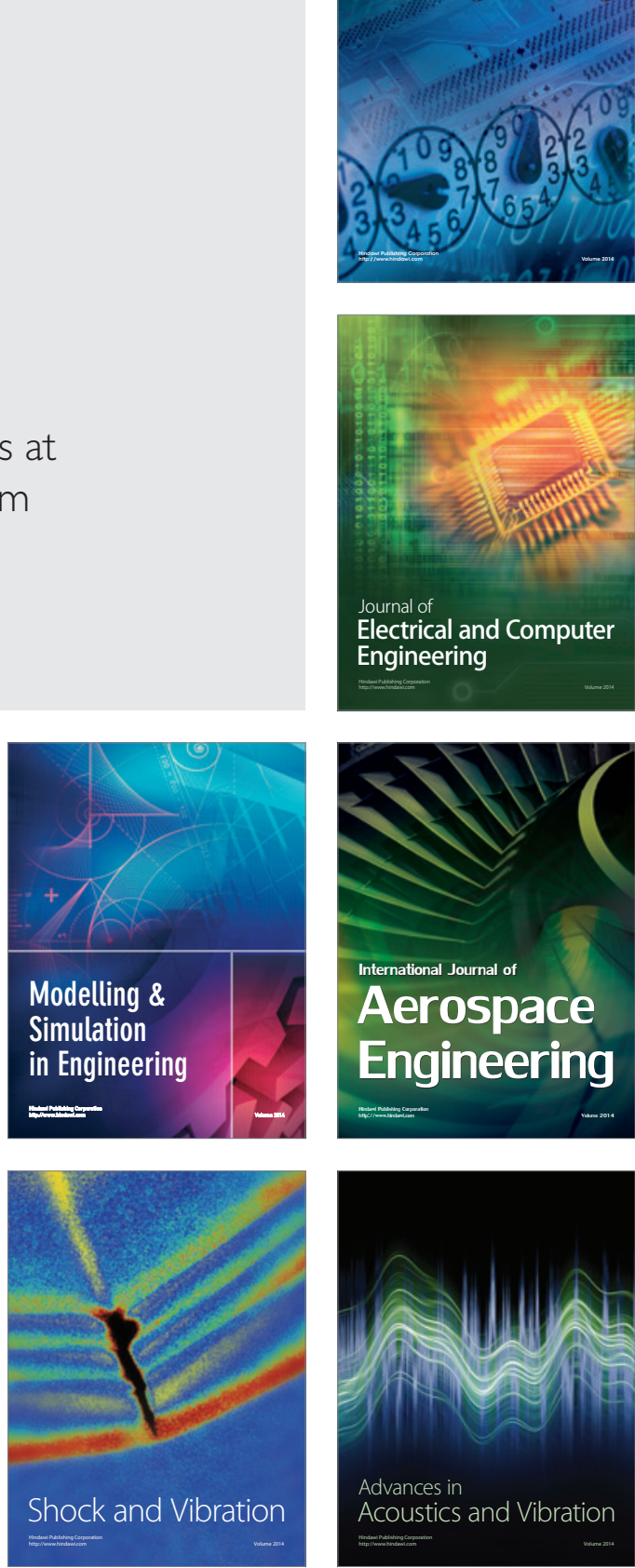